\title{
Railwaymen's Sight
}

In February, 1918,. we called attention to the urgency of the question of fixing some definite standard of vision for engine drivers in this country. We pointed out the chaotic condition of the present railway regulations and some of the difficulties that would require to be faced. Similar difficulties had to be faced and solved in dealing with the visual requirements of the Mercantile Marine. In the early part of this year the Council of British Ophthal- mologists appointed a committee to consider the question from the scientific standpoint, but although the project was regarded favourably by the Board of Trade, the opposition of the Governing body of the railways held up the work of the committee. The attention of the public has now been awakened to the urgency of the question by the strike on the North-Eastern Railway, and we understand that a national standard of eyesight for railway men has been promised. It is to be hoped, not only for the sake of the railway men themselves, but for the safety of the general public, that a genuine attempt will be made to arrive at some scientific standardization of the various visual factors which enable a man to be an efficient and safe driver. The following correspondence has recently appeared in THE TIMES :

\section{EYESIGHT TESTS.}

\section{To the Editor of The Times.}

SIR,-The strike on the North-Eastern Railway brings to the surface a grievance which has been agitating railwaymen for some considerable time. On the face of it, it seems obvious that eyesight tests are necessary, since the safety of the travelling public depends upon the good vision of engine-drivers and others. Yet it should not be too hurriedly concluded that the grievance is wholly illusory. It probably depends chiefly upon the unsatisfactory nature of the examinations, which do not enlist the confidence of the men. A similar. state of affairs existed some years ago in the mercantile marine. In this case a Departmental Committee was set up by the Board of Trade, their recommendations were adopted, and eventually both the shipping companies and the men's federation were so impressed with the fairness and adequacy of the tests that only sporadic cases of dissatisfaction now occur. So successful a precedent should influence the Board of Trade in dealing with the railway problem, which had, indeed, already been brought to their notice by the Council of British Ophthalmologists.

I am, Sir, yours faithfully, -

$$
1 \text { J. HERbert Parsons. }
$$

54, Queen Anne Street, Cavendish Square, W.1., July 17. 


\section{RAILWAYMEN'S SIGHT.}

To the Editor of The Times.

SIR,-In the early part of this year the Council of British Ophthalmologists appointed a committee to consider the standards of vision for men engaged in railway transport. There has been no scientific investigation of the problem in this country. The efficiency of the methods employed in different railways varies greatly, and they are not controlled by the Board of Trade. The purpose of the proposed committee was purely scientific, but for various reasons its work had to be suspended. Recent events have shown the urgency of the question, and the Council of British Ophthalmologists are quite ready at any time to give the expert aid that can only be given by ophthalmic surgeons.

Yours faithfully,

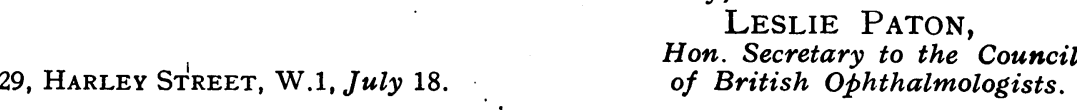

\section{RAILWAYMEN'S SIGHT.}

THE TEST IN USE.

To the Editor of The Times.

SIR,-In your issue of July $18 \mathrm{Mr}$. Herbert Parsons ventures the opinion that the present trouble on the North Eastern Railway "probably depends chiefly upon the unsatisfactory nature" of the company's eyesight examinations, "which do not enlist the confidence of the men." I do not gather that Mr. Parsons has taken the trouble to make inquiries as to the nature of the tests on the North Eastern Railway, or even as to whether it is a fact that the systems adopted are disapproved by the men, but your readers may like to know that the test which has given rise to the present trouble is one which was instituted at the request of the men themselves, viz., the test of stating the position of signals on a disused portion of railway at varying distances. This test is only made use of in the case of men who have failed to pass the ordinary type-reading test, and was adopted as a supplementary test to meet the view held by a number of railwaymen that an out-of-doors test is fairer and more reliable, in the case of men whose duties lie out of doors, than one made in a room.

I am, Sir, yours faithfully,

NeWCASTLE-ON-TyNe.

\section{A. Kaye Butterworth.}

\section{EYESIGHT TESTS.}

To the Editor of The Times.

SIR,-Sir A. Kaye Butterworth forgets the fact that people are not always satisfied when they get what they ask for. The demand for a so-called "Practical Test" is no new one. "Such a test, carried out in normal atmospheric conditions, would probably fail altogether to detect candidates whose abllity to distinguish between red, green, and white lights under less favourable conditions of weather is open to grave doubt." 
"The contention that persons who fail to pass an indoor test of colour vision may nevertheless be relied upon to distinguish accurately the colours of the lights which they meet with in the ordinary course of their duties at sea has been met by the results of the experiments conducted by the Committee at Shoeburyness." These are two of the comments on this point by the Departmental Committee of the Board of Trade on Sight Tests (Cd. 6256, p. 13, 1912). The Committee made exhaustive experiments at Shoeburyness, and, indeed, it was due to a demonstration carried out there in the presence of Mr. John Burns, then President of the Board of Trade, that both masters and men were convinced of the efficacy of the Board of Trade lantern. As, however, a national eyesight test has been agreed to, the interests of both the travelling public and the men will be safeguarded, and further comment is unnecessary.

I am, Sir, yours faithfully,

54, Queen Anne Street, W.1, July 21.

J. HERBERT Parsons.

\section{THE OXFORD OPHTHALMOLOGICAL CONGRESS, I9I9}

THE Tenth Annual Meeting of the Oxford Ophthalmological Congress was held on July 10th and 11th last in beautiful weather. Members were lodged in Keble College and the scientific proceedings took place in the Department of Human Anatomy of the University (kindly lent for the purpose by Professor Arthur Thomson), where technical and commercial museums were also arranged. The programme was opened on July 10th by an address of welcome by the Master. Major Walter H. Kiep, R.A.M.C., read a paper on the ocular complications of dysentery, which was followed by a good discussion on the subject. Major Edgar H. Smith, R.A.M.C., read a communication dealing with "Quinine Amaurosis," well discussed by the members present. Dr. William McLean, of New York, described his further experimental studies in intra-ocular pressure and tonometry, and exhibited his latest model tonometer. We hope to publish his paper in these columns shortly. The event of the meeting was a discussion on "Preventive Ophthalmology," introduced by Colonel J. Herbert Parsons, C.B.E., consulting ophthalmic surgeon to the Forces. Colonel Parsons pointed out that the scope of his subject dealt with the prevention of damage $(a)$ to the individual, and $(b)$ to others. (a) included many subjects, such as prevention of damage to the eyes from accidents, defective illumination, deleterious rays, and organisms, and the prevention of damage to health from headache, accident, fatigue, etc. (b) included regulations for the prevention of the transference of contagious disease and rules for Navy, Army, Air Force, Mercantile Marine, Railways, Motor Industry, Cinemas, and so forth. The problems of preventive ophthalmology constituted a question of collective 